The Three Parties in the Race to the Bottom: Host Governments, Home Governments and Multinational Companies

\author{
Rosanne Altshuler \\ Rutgers University \\ altshule@rci.rutgers.edu \\ Harry Grubert \\ U.S. Treasury and CESifo Network \\ harry.grubert@do.treas.gov
}

This draft: March 24, 2005

Nothing in this paper should be construed as reflecting the views and policy of the U.S.

Treasury Department. We are grateful for comments from Jack Mintz, Andrew Lyon and William Randolph. We thank Raymond Mataloni for help with the Department of Commerce data and Gordon Wilson for help with the tax return data. 


\title{
The Three Parties in the Race to the Bottom: Host Governments, Home Governments and Multinational Companies
}

\begin{abstract}
Most studies of tax competition and the race to the bottom focus on potential host countries competing for mobile capital, neglecting the role of corporate tax planning and of home governments that facilitate this planning. This neglect in part reflects the narrow view frequently taken of the policy instruments that countries have available in tax competition. For example, high-tax host governments can permit income to be shifted out to tax havens as a way of attracting mobile companies. Home countries will cooperate in this shift if they think the benefit to their companies is greater than any reduction in the domestic tax base. We use various types of U.S. data, including firm level tax files, to identify the role of the three parties (host governments, home governments and MNCs) in the evolution of tax burdens on U.S. companies abroad from1992 to 2002. This period is of particular interest because the United States introduced regulations in 1997 that greatly simplified the use of more aggressive tax planning techniques.

The evidence indicates that from 1992 to 1998 the decline in effective tax rates on U.S. companies was driven largely by host governments defending their market share. But after 1998, tax avoidance behavior seems much more important. Effective tax rates on U.S. companies had a much weaker link with local statutory tax rates. Furthermore, the disparity in the reported profitability of subsidiaries in high-tax and low-tax jurisdictions grew substantially.
\end{abstract}

After 1997, there was a very large growth in intercompany payments and a parallel growth of holding company income. We attempt to estimate how much of these payments were deductible in the host country, and conclude that by 2002 the companies were saving about $\$ 7.0$ billion per year by using the more aggressive planning strategies. This amounts to about 4 percent of foreign direct investment income and about 15 percent of their foreign tax burden. 


\section{The Three Parties in the Race to the Bottom: Host Governments, Home Governments and Multinational Companies}

The tax competition literature generally focuses on potential host countries competing for mobile capital. But there are two other participants that are important to the evolution of tax burdens, multinational companies that engage in various tax planning strategies and home governments that can facilitate the use of these strategies in order to bolster their companies’ competitiveness.

There has been a tendency to focus only on a narrow range of policy instruments that governments can use to attract companies, as reflected in effective tax rates that embody statutory tax rates, accelerated depreciation and investment credits. But host governments can use other inducements as well, such as lax thin capitalization rules that permit multinational companies (MNCs) to take large deductions for interest paid to affiliates offshore. At the same time home countries can cooperate in this strategy by allowing the use of tax haven finance affiliates for the receipt of this interest. This example illustrates the fact that tax competition cannot be gauged by straightforward bilateral effective tax rates because some subset of the participants can cooperate in the shifting of income to a third country. ${ }^{1}$

This paper uses data on the operations of U.S. companies abroad to illustrate the role of each of the actors in the reduction of corporate tax burdens. The period covered is from 1992 to 2002, with special emphasis on the period after 1996. In 1997, the U.S. Treasury issued regulations which were initially targeted on purely domestic businesses but had important international implications because they greatly simplified the use of more aggressive tax planning strategies. Indeed, we will see that the driving force behind the fall in effective tax rates on U.S. companies changed after 1996. Prior to then, there seemed to be pressure on countries that had lost market share to lower their effective tax rates. After 1996, the role of company tax saving strategies was much more evident.

\footnotetext{
${ }^{1}$ See Grubert (2004) for a discussion on how to construct measures of effective tax rates that reflect opportunities for various multilateral strategies.
} 
The paper proceeds as follows: First, the basics of the U.S. system for taxing foreign direct investment income will be described including the significance of the rules introduced in 1997. This provides the context for the various tax planning strategies that have become commonplace. Reviewing the details of the tax rules is necessary in order to make an accurate assessment of the tax burdens on cross-border investment. The incentives of host and home countries in the tax competition process will also be examined.

The empirical analysis looks at the issues from several angles using different types of data because tax strategies can use alternative structures that reveal themselves in a variety of ways. No single data set gives the complete picture. We begin with the evolution of the effective tax rates on the net income earned by U.S. manufacturing companies in approximately 60 countries from 1992 to 2000. This analysis provides suggestive evidence on the respective roles of the players. But country rates are not completely definitive because income in the form of interest or royalties could have been shifted to holding companies or finance affiliates in tax havens. This would not be captured in the country average effective tax rates for manufacturing subsidiaries. But data on foreign direct investment income and country affiliate income provided by the Bureau of Economic Analysis in the U.S. Commerce department allow us to estimate the growth of deductible payments paid to low-tax entities. In addition, Treasury tax data shows the growth of income in companies incorporated in low-tax countries. These tax haven corporations also record a large growth in plant and equipment, which must in fact be located in operations somewhere else, presumably in a high-tax country. This is facilitated by the new planning strategies described below, in which one subsidiary can invest in another but one of them can 'disappear' into a combined entity for U.S. tax purposes.

The comparison of subsidiary level Treasury data for 1996 and 2000 adds further evidence. These data permit an examination of the relationship between subsidiary effective tax rates and country statutory rates and whether it changed in 2000 compared to 1996 because of the new tax planning opportunities. We also attempt to see whether a greater share of income has been shifted to companies in low-tax countries. 
The results indicate that all three parties have played important roles in the decline in effective tax burdens since 1992. From 1992 to 1998, countries appeared to react to their past success, or the lack of it, in attracting U.S. investment. The countries that had lost market share cut their effective tax rates more. Also small countries, which would face the most elastic supply of foreign capital, continued to reduce their effective tax rates.

The new opportunities for tax avoidance introduced in 1997 seemed to be a much more important force from 1998 onward. Changes in market share were no longer significant determinants of effective tax rates and small countries were not the leading tax cutters. A country's initial statutory tax rate, which indicates the benefits to the company of shifting income out, became more important between 1998 and 2000. The role of the companies and the cooperation, or nonresistance, of home and host countries is confirmed in the subsidiary level data for 1996 and 2000. Controlled foreign corporation (CFC) effective tax rates in 2000 were much less closely correlated with the local statutory corporate tax rate than in 1996, suggesting that some profitable companies in high-tax locations were in a position to engage in 'self help' by taking advantage of the new planning opportunities. Furthermore the disparity of CFC profitability between hightax and low-tax countries widened substantially in 2000 compared to 1996. This might have happened, for example, if a highly profitable operation formerly incorporated in a high-tax location 'disappeared' into a low-tax sibling that had stripped income out of it. (This planning technique is described below.)

The surveys of direct investors by the Bureau of Economic Analysis (BEA) in the U.S. Commerce department show a very large increase in intercompany payments and in the income of holding companies abroad after 1997. This presumably resulted from the new planning structures facilitated by the 1997 regulations. But in interpreting this growth in intercompany income it is important to distinguish between deductible payments like interest and nondeductible payment like dividends paid out of after-tax income. Using two different BEA series, we conclude that approximately 40 percent of the growth of intercompany income was in the form of payments deductible in the host country (and presumably not taxable in the receiving country). We therefore estimate that the multinational corporations saved about $\$ 7$ billion in taxes in 2002 compared to what 
they would have paid if they continued to behave the same way as in 1997. This is about 4 percent of foreign direct investment income and more than 15 percent of total host country tax burdens. This shows that a large component of the falling burdens on mobile capital can be missed if the tax planning by the companies and the home and host country policies that permit this planning are ignored.

\section{The U.S Rules for Taxing Foreign Income and the New Planning Structures}

The United States imposes the corporate tax on all repatriated foreign income, which includes not only dividends but also interest, royalties and other foreign payments such as compensation for services performed abroad. The tentative U.S. tax can be reduced because of credits granted for foreign income taxes paid, including the underlying corporate tax paid on direct investment abroad, but the credit is limited to what the U.S. tax would have been on the foreign income.

The repatriation of net active business income can be deferred but this deferral privilege is not extended to certain types of 'tainted' income under what are generally referred to as Controlled Foreign Corporation (CFC) rules. This tainted income includes passive portfolio income and the payment of interest, dividends and royalties from one CFC to a CFC in another jurisdiction. Prior to 1997, U.S. companies could not therefore benefit from a tax haven finance subsidiary. In that scheme, equity is injected into a tax haven company which then lends to a high-tax subsidiary. The high-tax subsidiary then pays interest which is deductible against local taxable income to its tax haven affiliate.

The 1997 regulations introduced 'hybrid entities' which allowed U.S. companies to avoid the current tax under the CFC rules on intercompany payments like interest and royalties. (These regulations are sometimes referred to as 'check the box' because they gave companies the freedom to either identify an entity as a separate corporation or to 'disregard' it as simply as the unincorporated branch of another corporation by simply checking the box on a tax form.) Hybrid entities are business operations that are regarded as corporations by one country while being an unincorporated branch to another. In the tax haven finance affiliate example, the MNC could report to the U.S. Treasury that the high-tax affiliate is really an unincorporated branch of the tax haven company from which it has borrowed. The affiliate is still regarded as a corporation by the high-tax host 
country which grants a deduction for the interest going to the tax haven but the transaction is invisible to the U.S. Treasury which regards the combined tax haven-hightax operation as one consolidated corporation. The interest payment therefore escapes the CFC rules and the company can defer the income in the tax haven. The interest is not taxed anywhere. This example illustrates that 'standard' host country effective tax rates do not convey the complete picture in any race to the bottom.

What makes the use of these new planning structures difficult to identify in the data is that the MNC can elect to have either the high-tax corporation or its tax haven sibling disappear. In its reports to the Treasury, the surviving consolidated corporation can be listed as incorporated in either the high-tax location or the tax haven. It will therefore be necessary to piece together different types of data to get a more comprehensive picture.

Why would a home country allow this kind of method of stripping income from a high-tax location to a tax haven? It depends on its judgment on the consequences of lowering the tax burden on its companies in the high-tax location. If its home-based companies now shift to the high-tax location from foreign low-tax locations, from Ireland to Germany for example, both the world and the home country are better off. Capital has moved to a location with a higher pre-tax return. ${ }^{2}$

The high-tax host country could resist this income stripping strategy by enforcing 'thin capitalization' rules which limit the extent to which a company can leverage itself up, particularly when the interest is paid to related parties offshore. But it may not choose to do so as a way of discriminating in favor of internationally mobile companies that can take advantage of these income shifting strategies. This example also illustrates that tax competition can operate along many dimensions, not just in the lowering of statutory corporate tax rates or the granting of investment credits that tend to get the most attention.

Hybrid entities can also be used to route dividends to a holding company in a country with a favorable holding company regime, one that exempts dividends and has an extensive tax treaty network assuring low withholding taxes on dividends. Multinational

\footnotetext{
${ }^{2}$ Another way in which home countries increase the competitiveness of their companies is by not requiring them to allocate overhead expenses to foreign income. Thus a company can borrow at home and invest equity in a low-tax jurisdiction, thereby receiving a tax deduction for the interest while paying little or no tax on its earnings. Among the OECD countries, only the United States makes a serious effort to require interest allocations, and that is incomplete because it operates only through the foreign tax credit limitation.
} 
corporations frequently find it convenient to organize their foreign investments through holding companies. Inter-affiliate dividends can also be used to reduce the U.S. residual tax on repatriations from low-tax countries (see Altshuler and Grubert 2003). Without the use of a hybrid entity, the intercompany dividends would generally be subject to current U.S. tax. Hybrid entities make them invisible to the U.S. Treasury. Hybrids can thus be used to make either intercompany payments like interest and royalties that are deductible from host company taxable income, or dividends paid out of after-tax equity income. As a result, these payments can have differing implications for the tax burden on foreign investment. Distinguishing between the two will become an issue when we attempt to interpret the significance of the growth in intercompany payments documented in the Bureau of Economic Analysis surveys. (These differ from the Treasury data in that they keep the two entities that are combined in the Treasury data as separate affiliates.)

A further use of hybrid entities is to shift income from intellectual property like patents to tax havens by making the intercompany payment of royalties invisible. The tax haven entity can engage in a cost sharing agreement whereby it pays for part of the parent's R\&D project. This gives it the right to license the resulting technology to other foreign subsidiaries in exchange for royalty payments. Because the appropriate cost sharing payments and royalties are very uncertain, the MNC can attempt to underprice the former and overprice the latter, leaving a large amount of income in the tax haven. The royalty payments by the high-tax affiliate are not subject to the anti-abuse CFC rules because the tax haven entity and the high-tax affiliate can be declared as one consolidated incorporated subsidiary.

Hybrid securities are another planning device that can sometimes achieve the same results as hybrid entities. These are instruments that are regarded as debt by the host country and equity by the country to which income payments are made. They exploit the difficulties that tax authorities have in determining the distinction between tax deductible debt and taxable equity. These hybrid securities are particularly effective in saving taxes when the receiving country employs a dividend exemption or a 'territorial' system as it is sometimes referred to. Examples are the Netherlands, France and Canada which exempt dividends paid from an active direct investment abroad. Thus a Canadian company can capitalize an operating subsidiary in the United States with a hybrid security and receive 
payments that are deductible in the United States but exempt at home. Once again the income completely escapes taxation at the corporate level. Hybrid securities can be combined with hybrid entities to ensure a deduction in the paying host country, no tax in the receiving foreign country and no tax by the United States.

Grubert (2004) addresses the issue of how company and government behavior can impact effective tax rates. He shows that some of the most important features of a home country tax system for determining the tax burden on cross-border investment are rules that either limit or accentuate the ability of firms to use "self-help" techniques to lower their tax burdens. For example, Grubert's work demonstrates that whether companies can use tax haven finance subsidiaries or other aggressive planning schemes can have a profound impact on effective tax rates for investments abroad. These rules are shown to have a much larger impact on tax burdens for foreign investment than those relating to whether foreign income is exempt from home country taxation, for example.

\section{Data Sources}

The principal data source for this paper is the Treasury tax files for U.S. multinational corporations, in particular the Form 5471 which every U.S. parent company has to file for each of its controlled foreign corporations. This form provides information on the CFC's country of incorporation, and its sales, assets and intercompany transactions with related parties. It also contains information on foreign income taxes paid and a measure of net income defined in the Internal Revenue Code, referred to as Earnings and Profits, which approximates book income, not local taxable income. It is therefore possible to compute a consistent effective tax rate measure both for the country as a whole or for the individual subsidiary. In addition the basic corporate tax return, Form 1120 , is used for various parent characteristics such as R\&D intensity.

The surveys of foreign direct investment published by the Bureau of Economic Analysis in the Commerce Department are an alternative data source for studying MNC behavior. They are a useful supplement to the Treasury data because they define foreign affiliate income earned in a particular location in a different, and sometimes more convenient, way. 


\section{Country Average Effective Tax Rates, 1980-2000}

Table 1 presents the means and standard deviations of average effective tax rates for U.S. manufacturing subsidiaries in 58 countries. Host country average effective tax rates are calculated by dividing the total income taxes paid by U.S. CFCs in the manufacturing sector by their total earnings and profits (only CFCs with positive earnings and profits are included in the totals). The global means for each year presented in the table are an average of the effective tax rates in all 58 countries weighted by the number of CFCs in each country in 1990.

Altshuler, Grubert, and Newlon (2001) used these data to explicitly test whether the location of capital invested abroad by manufacturing affiliates of U.S. MNCs became more sensitive to differences in host country effective tax rates between 1984 and 1992. This work provides strong evidence that firms have indeed become more responsive to differences in tax rates.

In research using the same tax return data for 1984 through 1992, Grubert (2001) looked for changes in the behavior of both taxpayers and governments. Among other questions, he asked whether the behavior of governments during this period suggests more tax competition. Grubert found that smaller, poorer, and more open countries lowered their tax rates the most between 1984 and 1992. This is consistent with tax competition since one would expect that these countries would be most affected by the increased mobility of capital.

Here we focus on the period from 1992 to 2000. Table 1 shows that the decline in average effective tax rates documented in earlier work has continued. Since 1980, the global average effective tax rate has fallen by about 12 percentage points. The data shows a relatively large drop in effective tax rates between 1998 and 2000. It is also interesting to note that the distribution of worldwide tax rates has become tighter in the last decade (the standard deviation has fallen and increased relative to the mean) indicating some convergence in effective tax rates.

While we think it is possible that tax competition between countries is responsible for part of the drop in effective tax rates since 1992 (our initial year of analysis for this project), we suspect that the growth of hybrids (and thus company responses) may play an important role in explaining the most recent decreases in effective tax rates. For this reason 
we look at changes in country effective tax rates between 1992 and 1998 separately from the changes between 1998 and 2000.

We start by using simple regression analysis to test for evidence of tax competition in the period between 1992 and 1998. One test is whether country responses to changes in their share of U.S. capital explain changes in effective tax rates. We then look at the period between 1992 and 2000 to see whether the process explaining decreases in country effective tax rates have changed. Finally we focus on the last two years of data, 1998 and 2000, and test whether company versus country responses explain differences in the pattern of declines in effective tax rates across countries.

The data is subsidiary-level information from the Form 5471 aggregated up to the country level (for the same 58 countries used in table 1 and shown in the appendix). To control for heteroskedasticity, we weight by the number of CFCs in each country in 1992. The dependent variable is the change in a country's average effective tax rate (AETR) measured by subtracting the 1998 rate from the 1992 rate. Thus, if the change is positive (negative), effective tax rates have fallen (increased).

The main independent variable of interest is the percentage change in U.S. manufacturing affiliate capital, calculated by subtracting the log of real capital held by U.S. manufacturing affiliates in a country in 1984 from the log of real capital held in 1992. This is the change in capital studied in AGN so the data was readily available to us and convenient to use. Did the locations loosing market share feel pressure to lower their tax rates to compete?

In all of the regressions, we control for the country's initial level of effective tax rate and include a dummy variable that equals one if the country is "small” (has a population of less than 15 million in 1992). Note that we use the 1990 rate to control for the “initial” level of each country's effective tax rate. Including the 1992 effective tax rate in the regression could create a spurious correlation between the 1992-1998 change in tax rates and the 1992 rate. Furthermore, including a lagged value of the change in capital share ensures that this independent variable is not endogenous.

The results presented in table $2 \mathrm{~A}$ are suggestive of a tax competition story. The first column presents results from what we consider to be a basic test for tax competition. The coefficient on the change in capital share, log(capital in 1992) - log(capital in 1984), 
is negative and highly significant. Countries losing market share relative to their neighbors (those with the most to gain) cut their effective tax rates more between 1992 and 1998. Conversely, the higher was a country's increase in capital between 1984 and 1992, the smaller were their tax cuts.

Turning to the other independent variables we see that rates fell more for countries with higher initial effective tax rates. The estimated coefficient on the 1990 average effective tax rate variable is positive, large in magnitude, and statistically different from zero at more than a one percent confidence level. This is also consistent with a tax competition story. Those countries that had relatively high rates made adjustments to their tax structure that resulted in larger decreases in effective tax rates over the period 1992 to 1998. In a competitive environment, these countries would be the ones that feel the greatest pressure to reduce rates.

Finally, the coefficient on the dummy for small countries is positive and is also very significant again suggesting an international motivation for corporate tax reductions. Smaller countries, which may face the most elastic supply of capital, lowered effective tax rates relatively more than the average. Grubert (2001) found the same result in his analysis of the factors causing the fall in country average effective tax rates between 1984 and 1992. Interestingly, as we will see, this result vanishes when we focus on the changes in country effective tax rates between 1998 and 2000.

In the second column of table $2 \mathrm{~A}$ we show the results of a regression that includes a term that interacts the market share variable with the 1990 effective tax rate. This allows us to test, for example, whether countries that had gained market share between 1984 and 1992 and had relatively high effective tax rates felt less pressure to lower their tax rates. Alternatively, the question can be posed as follows: does the increase in capital mobility over the 1984-1992 period explain the pattern of declines in effective tax rates? The hightax countries that lost substantial market share would have been the most likely to conclude that capital mobility increased. Conversely the low-tax countries that did not gain or even lost would have felt no pressure to lower their tax rates any further. But, the estimated coefficient on the interaction term, shown in column 2, is not significantly different from zero. This suggests to us that the changes in effective tax rates between 1992 and 1998 are more the result of simple tax competition among countries than countries responding to 
recent increases in capital mobility.

The third column shows the result of a more sophisticated test designed to identify the role played by increased capital mobility. We start by using the coefficient estimates from the regression equation in AGN to predict the change in capital between 1984 and 1992. We then calculate the difference between the actual change in capital and the predicted change. Countries with more elastic supplies of capital will gain (lose) more capital when tax burdens are lowered (increased). To capture this, we interact the difference between the actual and predicted change in capital with the tax terms relevant for the change in capital (the 1984 effective tax rate and the difference in the 1984 and 1992 rates) and test whether the interacted term is a significant explanatory variable. Column 3 shows that the interaction term is not statistically different from zero. Although we plan to continue work on this topic, our results to date suggest that increased mobility does not explain movements in effective tax rates as well as simple differences in changes in capital shares.

We test whether changes in effective tax rates differ across regions in the fourth column of table 2A. Only the dummy variable for Latin America has an estimated coefficient that is statistically different from zero at conventional levels. Interestingly, the coefficient is negative which indicates that Latin American countries cut their rates less on average between 1992 and 1998. In an experiment that we do not report, we interact regional dummy variables for two areas of interest, the EEC and Asia, with the change in capital share variable (log of capital in 1992 - log of capital in 1984). Neither coefficient on the regional interaction terms were statistically different from zero which suggests that tax competition was no different on average in these regions.

Table 2B includes the 2000 data. As mentioned above, we are interested in exploring whether, in recent years, company rather than country behavior explains the pattern of decreases in effective tax rates. Accordingly, an important explanatory variable to include in the analysis is the statutory tax rate. The higher is this rate the greater the incentive to strip income out of high-tax countries with related party debt, for example, to lower the effective tax burden on investment. Thus, the extent to which company responses cause decreases in effective tax rates will be captured by the coefficient estimate on the statutory rate. If country responses are driving the effective tax rate reductions, we 
would not expect statutory rates to be correlated with changes in effective tax rates. Countries with high statutory rates and low effective tax rates, for example, would not feel pressure to lower effective tax rates to attract investment. As a result, the initial level of the statutory rate would not be a significant explanatory variable.

The first column of table 2B adds the statutory tax rate in 1992 to our regressions and shows that it is not statistically different from zero. These results change markedly when we extend our analysis to the year 2000. Changes in capital share no longer explain differences in effective tax rate decreases. And the statutory rate in 1992, while not significant at conventional levels has much greater explanatory power. This suggests to us that tax changes between 1998 and 2000 may be the result of a different dynamic than that explaining the 1992 to 1998 experience. Tax competition seems to explain the changes in rates between 1992 and 1998; company tax-minimizing behavior becomes important when we add the 2000 data. Although it is possible that countries are competing by lowering statutory corporate tax rates in order to attract base shifting, it is not clear why the pattern would change when we include the 2000 data. Table 3 takes a closer look at the last two years of our data.

As explained above, the incentive to use "self-help" tools such as hybrid entities to lower tax burdens depends on statutory tax rates. Earnings stripping, which can be accomplished through the use of hybrids, is beneficial when interest is deducted from an affiliate in a high statutory tax rate country and paid to an affiliate in a low (or no) statutory tax rate country. Table 3 begins by testing whether the 1996 average effective tax rate (we use the 1996 rate for the same reasons we used the 1990 rate in the table 2 regressions) or the statutory tax rate better explains differences in changes in average effective tax rates across countries between 1998 and 2000. Again the dependent variable is constructed to be positive when tax rates fall: it equals the AETR for 1998 minus the AETR for 2000.

The first two columns of table 3 test whether the average effective tax rate in 1996 explains any of the variation in the change in effective tax rates from 1998 to 2000. Note that the estimated coefficient on the 1996 rate while positive is not statistically different from zero at standard levels. Also, the coefficient on the small country dummy is no longer positive and is not statistically different from zero. The evidence for tax competition found in table 2A which examines the period from 1992 to 1998 is no longer evident. 
In columns 3 and 4 we substitute the statutory rate in 1998 for the AETR in 1996. This exercise provides some suggestive evidence that company rather than country behavior may be responsible for the decrease in effective rates between 1998 and 2000 . The estimated coefficient on the statutory rate is positive and significant at the 10 percent confidence level. However, when we add regional dummies to this regression (in column 4) the magnitude of the coefficient decreases and the standard error increases.

The final column of table 3 shows the results of the test of the tax competition story we explored in tables 2A and 2B. Not surprisingly given the results in the last column of table $2 \mathrm{~B}$, the change in capital share variable is not significantly different from zero. Although only suggestive, our results point to company behavior and not tax competition explaining changes in effective tax rates in the most current data.

\section{Tax planning and changes in firm level effective tax rates}

The subsidiary level data from Form 5471 may be used to shed more light on the question of whether company tax planning behavior made possible by the recent changes in the tax rules explains the latest reductions in effective tax rates. We cannot directly observe the extent to which tax planning has lowered CFC effective tax rates. However, we can determine whether factors explaining the variation in company effective tax rates have changed in recent years. For instance, one would expect statutory tax rates and effective tax rates to be highly correlated. But 'check the box' and the opportunity to use hybrid securities to strip income out of high-tax countries may weaken this relationship. The regressions shown in table 4 explore whether determinants of CFC effective tax rates such as statutory rates have changed in a way that is consistent with the use of tax planning techniques. $^{3}$ The empirical work uses the 1996 and 2000 CFC level Form 5471 data matched to parent data from the Treasury tax return files. As in our previous work, we include only manufacturing CFCs of U.S. manufacturing parents.

The dependent variable in the table 4 regressions is the CFC effective tax rate. Independent variables include the country statutory rate and both parent and subsidiary specific information. Note that in table 4 we show the results of regressions in which the

\footnotetext{
${ }^{3}$ The subsidiary level regressions include observations in Bermuda and the Cayman islands in addition to the 58 listed in the appendix.
} 
CFC observations are unweighted and also those weighted by sales to correct for heteroskedasticity.

As mentioned above, if companies have increasingly used hybrids, we would expect the significance of the statutory rate in explaining effective tax rates to decrease since some are presumably in position to take advantage of the new planning structures while others are not due to host country provisions or particular company circumstances. This is born out by the regression results. The coefficient on the statutory rate is smaller and much less statistically significant in the 2000 regressions than in the 1996 regressions. ${ }^{4}$ The t-statistics in the unweighted (weighted) regression falls from 13.7 (21.1) to 7.7 (10.2). The lower adjusted R-squared in the 2000 regression is consistent with the weaker explanatory power of the statutory rates.

Note that the constant term in the regressions rose substantially in 2000, suggesting that at the low end effective tax rates were higher for any given statutory rate. These would reflect the cases in which the subsidiary incorporated in a low-tax country is the surviving entity and some of the tax was in fact paid to the high-tax jurisdiction. The lower effective tax rate at high statutory tax rates would reflect the cases in which the consolidated operation is still incorporated in the high-tax location but some of the income has not been subject to tax there.

The role of profitability in explaining differences in effective tax rates has also changed. One would expect that the more profitable CFCs would have higher effective rates since they pay the statutory rate on the margin. At the same time, however, the more profitable CFCs have a greater incentive to use hybrids and other planning techniques to strip income from their tax base. Our regression results show that in 1996, differences in profitability explained none of the variation in CFC effective tax rates (the coefficient is not statistically different from zero). In 2000, however, the coefficient on CFC earnings and profits (as a percentage of sales) was negative and statistically different from zero at conventional levels. Higher profitability in a country is now associated with lower effective tax rates.

\footnotetext{
${ }^{4}$ One possible explanation for the low statutory tax rate coefficient might simply be that CFC effective rates on average fell relative to statutory rates. But, in fact, that is not true in comparing the 1996 and 2000 samples. The sample average effective rate dropped from 23.5 percent to 21.5 percent while the sample statutory rate fell proportionately more, from 35.4 percent to 31.8 percent.
} 
We also find a difference in the role of parent R\&D intensity across the two years. In 1996, parent R\&D intensity had a positive and significant effect on CFC effective tax rates. This suggests rent extraction by host countries who believe that, for most intangibles assets like patents, the MNC has to produce locally in order to be in the market. As we explained above, however, check the box made it easier to lower effective tax rates in high-tax countries through cost sharing agreements. Our regression results provide some suggestive evidence of this tax planning behavior. The coefficient on parent R\&D intensity is smaller in magnitude and significance in 2000 compared to 1996. In the weighted regression results, the coefficient actually becomes negative and highly significant statistically. Higher R\&D expenditures at the parent level, all else equal, are associated with lower effective tax rates at the CFC level in $2000 .^{5}$

\section{Evidence on the Growth of Income Shifting at the Subsidiary Level}

The observation that reported profitability is much higher in low-tax countries than high-tax countries, suggesting tax induced income shifting, goes back a long way, at least to Grubert and Mutti (1991). These differences in profitability could be attributable to the shifting of debt, and therefore interest deductions, to high-tax jurisdictions, the manipulation of transfer prices for goods and services, or the failure to pay adequate royalties for intellectual property contributed by the parent company. Here we attempt to see whether the new opportunities for tax avoidance made possible by recent regulatory changes, and the possible complaisant attitude of the high-tax host countries wishing to attract investment, contributed to a widening of the profitability difference between high and low-tax countries. The effective tax rate relevant for investment in a location should be reduced to reflect the opportunities created by the investment for shifting income in (for low-tax countries) or out (for high-tax countries). (See Grubert (2004) for a discussion of revising effective tax rates to reflect income shifting.)

\footnotetext{
${ }^{5}$ Another piece of evidence consistent with an increase in hybrids is that there are less CFCs in the 2000 sample than in the 1996. There were about 600 fewer manufacturing CFCs among the top 7,500 (in terms of assets or sales) in 2000. Some of the highly profitable CFCs in high-tax locations may now be consolidated with another manufacturing CFC using a hybrid, or the surviving consolidated entity may now be classified in some nonmanufacturing industry. Another possibility is the change to the system of classification (NAICS) that may have resulted in some companies formerly in manufacturing ending up in other classifications such as software. As we will see below, the total number of manufacturing CFCs did grow from 1996 to 2000.
} 
Tables 5A and 5B therefore compare income shifting behavior in 1996 and 2000. Table 5A includes all manufacturing CFCs with positive profits while Table 5B includes only the manufacturing subsidiaries among the 7500 largest. The dependent variable in each of the regressions is the ratio of pre-tax profits to sales. The explanatory variables are two dummies for CFC age, the R\&D and advertising intensity of the parent, and the local statutory tax rate. The latter indicates the incentive to shift income in or out because it is the tax paid or saved on a marginal dollar of income. As expected, the R\&D and advertising intensity of the parent are significant contributors to CFC profitability. The shifting variable, the statutory tax rate, has the expected negative sign and is highly significant in all the regressions. But what is notable is that the coefficient for 2000 is significantly larger in absolute value than the 1996 coefficient, by about two thirds. There indeed seems to have been a significant widening in the profitability disparities between high-tax and low-tax countries.

This evidence of growing profitability disparities has several possible explanations. High-tax host countries may have reacted to the increasing tax sensitivity of investment by easing up on their transfer pricing and thin capitalization rules in order to attract mobile corporations. It could be that some highly profitable subsidiaries in high-tax countries 'disappeared' as separate CFCs and became part of a consolidated entity based in a tax haven and are classified as holding companies. (The consolidated entities that survive as high-tax corporations in the Treasury files explain the negative coefficient for profits in the effective tax rate regressions for 2000 in the previous section. For both structures, the most profitable companies are the ones most likely to avail themselves of the new planning strategies.) Some consolidated entities listed in tax havens do continue to be classified in manufacturing and are therefore included as observations in our regressions. In fact, this explains part of the apparent growing amount of income shifting. In some of the regressions, such as the unweighted regressions in Table 5B, the increase in the shifting coefficient shrinks by almost one half when CFCs in two 'pure' tax havens with no actual manufacturing, Bermuda and the Cayman Islands, are excluded from the regressions. (The next section examines more aggregated data on CFCs incorporated in tax havens and their real investment that must be located elsewhere.) 
In summary, these subsidiary level data suggest the growing use of aggressive strategies, with the cooperation of host and home countries, to lower tax burdens on direct investment abroad. The next two sections use more aggregate data on income and capital from both the Treasury files and the Bureau of Economic Analysis to supplement this picture.

\section{Evidence on the location of income and real capital}

Further insight on self-help and its impact on the location of income can be obtained from table 6 which presents selected tabulations from the Treasury Form 5471 files for 1996 and 2000. The first two rows confirm that earnings in seven major low-tax countries grew much more rapidly than total earning and profits of all U.S subsidiaries. The next row shows that a part of this "excess" growth of income in these locations, perhaps a third, is attributable to the growth in dividends. ${ }^{6}$ The remainder reflects both increased real activity and increased tax planning. As we have noted, tax planning cannot be identified in the Treasury data exclusively based on the country of incorporation of the reporting CFC. With a low-tax company being the disregarded entity that disappears from the Treasury's vision, the consolidated income would still be lodged in a CFC incorporated in a high-tax country even though some had been stripped out. (The effective tax rate regressions above, which showed the lower correlation with local statutory rates and the negative influence of profitability, reflected this structure. As explained further below, the Bureau of Economic Analysis (BEA) data captures both structures because both locations are given separately, with one owning an interest in the other.)

The next two rows provide further evidence of the hybrid structure in which the hightax company disappears. Total tangible capital in all locations grew by 28 percent from 1996 to 2000. But in five low-tax countries in which holding company income or intercompany equity income is a disproportionate share of income, tangible capital grew by almost 200 percent. Indeed, by 2000 tangible capital in these countries accounted for about 15 percent of all capital abroad. Most of this growth must reflect the consolidation of the low-tax CFC with the operations of a high-tax affiliate.

\footnotetext{
${ }^{6}$ Note that these figures do not include dividends received by hybrid entities in low-tax countries since information on these operations does not appear in the Form 5471 file.
} 


\section{Evidence on tax planning in the BEA data}

Sullivan (2004) reports a dramatic increase in U.S. profits reported abroad in low-tax countries between 1999 and 2002. (His analysis received wide coverage in the U.S. press.) According to BEA data, the pre-tax profits of foreign subsidiaries grew from \$207 billion in 1999 to $\$ 255$ billion in 2002. This 23 percent increase in foreign profits was dwarfed by the growth of profits in 18 countries Sullivan denotes as tax havens. Profits in these countries increased 68 percent over the same period from \$88 billion in 1999 to $\$ 149$ billion in 2002. Sullivan calculates the share of foreign profits as well as effective tax rates by country for both 1999 and 2002. Almost one-third (31 percent) of profits were “located" in Luxembourg, Ireland, Bermuda, and Singapore in 2002 (up from 15 percent in 1999). Effective tax rates fell over the sample period from 22 percent in 1999 to 20 percent in 2002. For some countries the decrease in effective tax rates was extreme. The effective tax rates for Spain, Belgium, Denmark, Luxembourg, Portugal and New Zealand fell by half or more.

\section{The double counting problem}

Sullivan uses data tabulated by country on the income of majority-owned foreign affiliates ("MOFAs") based on annual surveys compiled by the BEA. A MOFA is a foreign affiliate in which the combined direct and indirect ownership interest of all U.S. parents exceeds 50 percent. Among other items, the parent is asked to provide income and balance sheet information for each MOFA. An advantage of this dataset is that unlike in the case of the Treasury Form 5471 data, these data include information for the 'disregarded' hybrid entities.

U.S. parents are instructed to include income from equity investments in foreign affiliates in their report of total income for each MOFA. If the inter-company payment is a dividend paid out of net income, it will continue to be counted in the paying company's profits. As a result, these data reflect double counting of inter-company dividends. To see why this would cause a problem in analyzing this data, consider the following example. Suppose a U.S. parent fully owns a holding company in country A that has no corporate income tax. Suppose further that the holding company in country A fully owns a manufacturing affiliate in country B that generates $\$ 1,000$ in pre-tax profits. Assume that country B has a corporate statutory rate of 40 percent. For simplicity, suppose that the 
affiliate in country B remits all $\$ 600$ of after-tax profits to the holding company in the form of a dividend payment. Income earned in the manufacturing affiliate in country B will be reported on the information form the parent files for this indirectly held affiliate. Importantly, the income earned in the country B affiliate will also be reported on the information form the parent files for the holding company in country A. Instead of showing $\$ 600$ in after-tax total affiliate profits, the BEA data shows $\$ 1,200$.

This potential double counting of lower-tier profits presents serious problems in the interpretation of this affiliate income data. Continuing with our example using the years 1999 to 2002, assume that the profits of the manufacturing affiliate in country B did not change between 1999 and 2002 but the parent inserted the holding company in our example between itself and country B during this period (in other words, the holding company in country A did not exist in 1999). The BEA MOFA data would show a 60 percent increase in worldwide pre-tax profits (from $\$ 1000$ to $\$ 1600$ ) even though there was no change in these profits and no tax savings. Further, since country A would be classified as a tax haven country and country B would not, the data would depict a dramatic growth of profits in tax havens (from $\$ 0$ to $\$ 600$ ). Note that if the affiliate in country B made a deductible payment to the tax haven affiliate in country A, pre-tax income would increase by the amount of the payment in country A and fall by the same amount in country B leaving total affiliate income unchanged. ${ }^{7}$

\section{Implications of the growth of equity income from foreign affiliates}

Our simple example shows the importance of inter-company equity income in explaining the growth of affiliate profits abroad. The equity in the income of foreign affiliates has increased very rapidly in recent years. Table 7 shows information on the growth of equity income from the BEA data. From 1997, when 'check the box' was implemented, to 2002 this inter-company equity income rose from $\$ 40.7$ billion to $\$ 120.8$ billion. Indeed, table 7 shows that almost 100 percent of the growth in income in the seven major low-tax countries (Bermuda, the Cayman Islands, Ireland, Singapore, the Netherlands, Luxembourg and Switzerland) from 1997 to 2002 can be accounted for by this inter-company equity income.

\footnotetext{
${ }^{7}$ See Borga and Mataloni (2001) for a discussion of the problems created for the BEA direct investment data by the rise of holding companies.
} 
It is difficult to interpret the significance of this inter-company equity income for worldwide tax payments from just the affiliate income data alone. It could just represent inter-company dividends paid up to holding companies. In that case the income paid out by the lower tier company still bears a tax in its host country as before. As we saw in the discussion of hybrids, check the box makes it easier to avoid a current on inter-company dividends under the CFC rules. On the other hand, these inter-company payments may be deductible in the host country. As noted above, if the inter-company payments are deductible, then any increased income in the receiving country would just be offset by a reduction in net income in the paying country. Total affiliate income would not increase. But if the payments are nondeductible dividends, there would be an equivalent increase in inter-company income and total, double counting distorted, affiliate income. How much of the increase in affiliate income is associated with deductible tax payments and thus lower host country taxes? To estimate this breakdown, it is necessary to know how much total affiliate income would have grown for other reasons, unrelated to inter-company income.

This puzzle regarding deductible versus nondeductible payments can be solved by using another BEA series, "Foreign Direct Investment Income” which is computed for the Balance of Payments. This income is not double counted and tells us how affiliate net income evolves unrelated to double counting issues. The two series do not have exactly the same coverage because the foreign direct investment ("FDI") series includes income earned by affiliates that are not majority owned. However, the overwhelming component of the FDI income is the income of majority owned affiliates. We will assume that the share of non-majority owned income in the total remains constant over the 1997 to 2002 period in our calculations.

In 1997, total pre-tax affiliate income (from the MOFA data), including double counting, was $\$ 188.1$ billion and of this, equity income was $\$ 41.8$ billion. Foreign direct investment income (from the FDI data), adjusted for host country corporate tax (from the MOFA data), was $\$ 157.0$ billion. By 2002 this foreign direct investment income had increased to $\$ 174.3$ billion, or by 11.02 percent. If total affiliate income and equity income had continued to bear the same relationship to foreign direct investment income as in 1997, total affiliate income would have increased to $\$ 208.8$ billion and equity income would have increased to $\$ 46.4$ billion. In fact inter-company equity income increased to $\$ 120.8$ billion, 
or $\$ 74.4$ billion more than projected. Furthermore, total affiliate income rose to $\$ 255.2$ billion, $\$ 46.4$ billion more than projected if the relationship to foreign direct investment income had remained unchanged. This $\$ 46.4$ billion of “excess” total affiliate income represents "true" double counting, that is, increased inter-company equity income that is not offset by a reduction in net income in the paying country. Accordingly, 46.4/74.4, or 62.3 percent of the greater than expected increase in equity income represents double counting.

Our calculation leaves $\$ 28$ billion of inter-company income that was apparently deductible by the paying company. To estimate the amount of tax saving, we assume an average tax rate of 25 percent in the paying corporation's country and no tax in the receiving company's country, either because it is a tax haven or has a dividend exemption system in which hybrid securities can be used. We also assume that the book income data reported to BEA is consistent with the taxable income reported to the respective governments. Accordingly we estimate that these arrangements have generated an annual foreign tax saving of approximately $\$ 7$ billion in 2002, or about 4 percent of total foreign affiliate income reported in the MOFA data.

\section{Conclusions}

The various types of evidence used in this paper show the role of the various parties in the decline of tax burdens on multinational companies from 1992 to 2002. In the early part of the period, from 1992 to 1998, the decline in tax burdens seemed primarily driven by the host countries' desire to compete and defend their market share. From 1998 onwards the tax planning by the companies seems much more significant, facilitated by more permissive U.S. rules introduced in 1997. High-tax host countries had to acquiesce in this income shifting, perhaps because it was a way of favoring more mobile capital. The results illustrate the importance of including both company tax planning and the cooperation of home and host governments in an accurate depiction of any race to the bottom. For example, we estimate that in 2002 U.S. companies paid \$7 billion less in host country taxes compared to 1997 by using intercompany payments deductible in the paying country but exempt from tax in the recipient. This amounted to about 4 percent of total direct investment income, a substantial reduction in such a short period. 


\section{References}

Altshuler, Rosanne, and Harry Grubert. 2003, "Repatriation Taxes, Repatriation Strategies, And Multinational Financial Policy.” Journal of Public Economics 87 No.1: 73-107.

Altshuler, Rosanne and Harry Grubert, 2004, “Taxpayer Responses to Competitive Tax Policies and Tax Policy Responses to Competitive Taxpayers: Recent Evidence,” Tax Notes International, June 28, 34 (13): 1349-1362.

Altshuler, Rosanne, Harry Grubert, and T. Scott Newlon, 2001, "Has U.S. Investment Abroad Become More Sensitive to Tax Rates ?” in: James R. Hines, Jr. (editor), International Taxation and Multinational Activity, University of Chicago Press, 932.

Borga, Maria and Raymond Mataloni, 2001, "Direct Investment Positions for 2000” Survey of Current Business, Volume 81: 16-29.

Grubert, Harry, 2001, “Tax Planning by Companies and Tax Competition by Governments: Is There Evidence of Changes in Behavior?” in: James R. Hines, Jr. (editor), International Taxation and Multinational Activity, University of Chicago Press: 113-139.

Grubert, Harry, 2004, “The Tax Burden on Cross-Border Investment: Company Strategies and Country Responses.” in: Measuring the Tax Burden on Labor and Capital, edited by Peter Birch Sorensen. Cambridge, Massachusetts: MIT Press (CESifo Seminar Series): 129-170.

Grubert, Harry and John Mutti, 1991, "Taxes, Tariffs and Transfer Pricing in Multinational Corporation Decision Making." Review of Economics and Statistics 33: 285-293.

Sullivan, Martin, 2004, “Data Show Dramatic Shift of Profits to Tax Havens,” Tax Notes, September 13: 1190-1200. 
Table 1

Average Effective Tax Rates in Manufacturing for 58 Countries

(weighted by number of CFCs in each country in 1990)

\begin{tabular}{ccc}
\hline Year & $\begin{array}{c}\text { Average Effective } \\
\text { Tax Rate }\end{array}$ & $\begin{array}{c}\text { Standard } \\
\text { Deviation }\end{array}$ \\
\hline 1980 & 0.33 & 0.85 \\
1982 & 0.34 & 0.98 \\
1984 & 0.34 & 1.03 \\
1986 & 0.32 & 1.05 \\
1988 & 0.31 & 1.09 \\
1990 & 0.26 & 0.89 \\
1992 & 0.25 & 0.86 \\
1994 & 0.22 & 0.72 \\
1996 & 0.23 & 0.79 \\
1998 & 0.24 & 0.77 \\
2000 & 0.21 & 0.67 \\
\hline \hline
\end{tabular}


Table 2A

Do Changes in Capital Share Explain Recent Decreases in Country Average Effective Tax Rates (AETRs)?

\begin{tabular}{|c|c|c|c|c|}
\hline \multirow[b]{2}{*}{ Independent Variables: } & \multicolumn{4}{|c|}{$\begin{array}{c}\text { Dependent Variable: } \\
\text { AETR for 1992-AETR for } 1998\end{array}$} \\
\hline & (1) & (2) & (3) & (4) \\
\hline Log (capital in 1992) - log (capital in 1984) & $\begin{array}{l}-0.047^{\star \star \star} \\
(0.014)\end{array}$ & $\begin{array}{l}-0.047 \\
(0.038)\end{array}$ & & $\begin{array}{l}-0.055^{\star \star \star x} \\
(0.014)\end{array}$ \\
\hline Average Effective Tax Rate for 1990 & $\begin{array}{l}0.249^{* \star *} \\
(0.082)\end{array}$ & $\begin{array}{l}0.249^{\star *} \\
(0.118)\end{array}$ & $\begin{array}{l}0.334^{* \star *} \\
(0.088)\end{array}$ & $\begin{array}{l}0.193^{* *} \\
(0.080)\end{array}$ \\
\hline Dummy for small countries & $\begin{array}{l}0.049^{* \star \star} \\
(0.018)\end{array}$ & $\begin{array}{c}0.049^{* \star} \\
(0.018)\end{array}$ & $\begin{array}{l}0.052^{\star * \star} \\
(0.019)\end{array}$ & $\begin{array}{l}0.053^{\star \star \star} \\
(0.018)\end{array}$ \\
\hline $\begin{array}{l}\text { [Log (capital in 1992) - log (capital in 1984)] * AETR } \\
\text { for } 1990\end{array}$ & & $\begin{array}{l}.001 \\
(0.119)\end{array}$ & & \\
\hline $\begin{array}{l}\text { Predicted - actual change in log of capital between } \\
1992 \text { and } 1984\end{array}$ & & & $\begin{array}{l}-0.035 \\
(0.022)\end{array}$ & \\
\hline $\begin{array}{l}\text { [Predicted - actual change in log of capital between } \\
1992 \text { and 1984] * [tax determinants of investment] }\end{array}$ & & & $\begin{array}{l}0.053 \\
(0.064)\end{array}$ & \\
\hline \multicolumn{5}{|l|}{ Regional dummies } \\
\hline Latin America & & & & $\begin{array}{l}-0.049^{*} \\
(0.026)\end{array}$ \\
\hline North America & & & & $\begin{array}{c}0.020 \\
(0.027)\end{array}$ \\
\hline Asia & & & & $\begin{array}{l}0.025 \\
(0.025)\end{array}$ \\
\hline EEC & & & & $\begin{array}{l}-0.032 \\
(0.021)\end{array}$ \\
\hline Constant & $\begin{array}{l}-0.027 \\
(0.030)\end{array}$ & $\begin{array}{l}-0.027 \\
(0.036)\end{array}$ & $\begin{array}{l}-0.090^{\star \star *} \\
(0.027)\end{array}$ & $\begin{array}{l}0.005 \\
(0.034)\end{array}$ \\
\hline Adjusted $\mathrm{R}^{2}$ & 0.27 & 0.25 & 0.19 & 0.39 \\
\hline
\end{tabular}

Notes: See paper for details on the construction of the variables in the column 3 regressions. The dummy for small countries equals one for countries with populations below 15 million in 1992. All regressions are weighted least squares using the number of CFCs in 1992 as weighting factors. Number of observations equals 58. ${ }^{*},{ }^{* *},{ }^{* \star *}$ denote significance at the 10 percent, 5 percent, and 1 percent levels respectively. The mean of the dependent variable in .009. 


\section{Table 2B \\ Do Changes in Capital Share Explain Recent Decreases in Country Average Effective Tax Rates? \\ 1998 versus 2000}

\begin{tabular}{lcc}
\hline \hline & \multicolumn{2}{c}{ Dependent variable: } \\
Independent Variables: & $\begin{array}{c}\text { AETR for 1992- } \\
\text { AETR for 1998 }\end{array}$ & $\begin{array}{c}\text { AETR for 1992- } \\
\text { AETR for 2000 }\end{array}$ \\
\hline Log (capital in 1992) - log (capital in 1984) & $-0.055^{* * *}$ & -0.024 \\
& $(0.015)$ & $(0.015)$ \\
Average Effective Tax Rate for 1990 & $0.205^{*}$ & 0.144 \\
Dummy for small countries & $(0.121)$ & $(0.124)$ \\
& $0.052^{* * *}$ & $0.032^{*}$ \\
Statutory rate for 1992 & $(0.018)$ & $(0.019)$ \\
Regional dummies & -0.016 & 0.166 \\
Latin America & $(0.117)$ & $(0.120)$ \\
North America & & \\
Asia & & -0.022 \\
EEC & $(0.026)$ & $(0.027)$ \\
& 0.020 & 0.023 \\
Constant & $(0.027)$ & $(0.028)$ \\
& 0.025 & 0.031 \\
Adjusted R & $(0.025)$ & $(0.026)$ \\
\hline \hline
\end{tabular}

Notes: The dummy for small countries equals one for countries with populations below 15 million in 1992. All regressions are weighted least squares using the number of CFCs in 1992 as weighting factors. Number of observations equals 58. ${ }^{*},{ }^{\star *},{ }^{* \star *}$ denote significance at the 10 percent, 5 percent, and 1 percent level respectively. The mean of the dependent variable is .009 in column 1 and .035 in column 2. 
Table 3

Analysis of Change in Country Average Effective Tax Rates

between 1998 and 2000:

Country versus Company Responses?

\begin{tabular}{|c|c|c|c|c|c|}
\hline \multirow[b]{2}{*}{ Independent Variables: } & \multicolumn{5}{|c|}{$\begin{array}{c}\text { AETR for } 1998-\text { AETR for } 2000 \\
\text { Dependent variable: }\end{array}$} \\
\hline & (1) & $(2)$ & (3) & $(4)$ & (5) \\
\hline AETR for 1996 & $\begin{array}{l}0.100 \\
(0.064)\end{array}$ & $\begin{array}{c}0.102 \\
(0.067)\end{array}$ & & & \\
\hline Statutory rate for 1998 & & & $\begin{array}{l}0.102^{*} \\
(0.061)\end{array}$ & $\begin{array}{l}0.077 \\
(0.066)\end{array}$ & $\begin{array}{l}0.095 \\
(0.063)\end{array}$ \\
\hline Log (capital in 98) - log (capital in 92) & & & & & $\begin{array}{l}-0.005 \\
(0.013)\end{array}$ \\
\hline Dummy for small countries & $\begin{array}{l}-0.018 \\
(0.013)\end{array}$ & $\begin{array}{l}-0.017 \\
(0.014)\end{array}$ & $\begin{array}{l}-0.017 \\
(0.013)\end{array}$ & $\begin{array}{l}-0.018 \\
(0.014)\end{array}$ & $\begin{array}{l}-0.016 \\
(0.013)\end{array}$ \\
\hline \multicolumn{6}{|l|}{ Regional dummies } \\
\hline Latin America & & $\begin{array}{l}0.026 \\
(0.020)\end{array}$ & & $\begin{array}{c}0.022 \\
(0.020)\end{array}$ & \\
\hline North America & & $\begin{array}{l}0.008 \\
(0.021)\end{array}$ & & $\begin{array}{c}0.005 \\
(0.021)\end{array}$ & \\
\hline Asia & & $\begin{array}{l}0.020 \\
(0.019)\end{array}$ & & $\begin{array}{l}0.019 \\
(0.019)\end{array}$ & \\
\hline EEC & & $\begin{array}{l}0.035^{* *} \\
(0.016)\end{array}$ & & $\begin{array}{l}0.031^{*} \\
(0.016)\end{array}$ & \\
\hline Constant & $\begin{array}{c}0.009 \\
(0.018)\end{array}$ & $\begin{array}{l}-0.014 \\
(0.024)\end{array}$ & $\begin{array}{l}-0.003 \\
(0.023)\end{array}$ & $\begin{array}{l}-0.013 \\
(0.028)\end{array}$ & $\begin{array}{l}0.001 \\
(0.026)\end{array}$ \\
\hline Adjusted $\mathrm{R}^{2}$ & 0.09 & 0.12 & 0.09 & 0.11 & 0.08 \\
\hline
\end{tabular}

Notes: The dummy for small countries equals one for countries with populations below 15 million in 1992. All regressions are weighted least squares using the number of CFCs in 1992 as weighting factors. Number of observations equals 58. ${ }^{*},{ }^{* *},{ }^{* * *}$ denote significance at the 10 percent, 5 percent, and 1 percent level respectively. The mean of the dependent variable is .026 . 
Table 4

The Relationship Between Effective and Statutory Tax Rates at the CFC Level A Comparison of 1996 and 2000

\author{
Dependent Variable $=$ CFC Effective Tax Rate
}

\begin{tabular}{|c|c|c|c|c|}
\hline Ind nondont Y & Unweighted & Unweighted & $\begin{array}{c}\text { Weighted } \\
\text { by sales }\end{array}$ & $\begin{array}{c}\text { Weighted } \\
\text { by sales }\end{array}$ \\
\hline Country statutory rate & $\begin{array}{l}0.508^{\star \star *} \\
(0.037)\end{array}$ & $\begin{array}{l}0.398^{k \star k} \\
(0.052)\end{array}$ & $\begin{array}{l}0.717^{* \star *} \\
(0.034)\end{array}$ & $\begin{array}{l}0.509^{\star \star *} \\
(0.050)\end{array}$ \\
\hline CFC age $<5$ years & $\begin{array}{l}-0.066^{\star \star *} \\
(0.014)\end{array}$ & $\begin{array}{l}-0.075^{\star \star *} \\
(0.014)\end{array}$ & $\begin{array}{l}-0.001 \\
(0.015)\end{array}$ & $\begin{array}{c}-0.050^{\star \star *} \\
(0.013)\end{array}$ \\
\hline CFC age $5-15$ years & $\begin{array}{l}-0.018^{*} \\
(0.010)\end{array}$ & $\begin{array}{l}-0.024^{\star *} \\
(0.012)\end{array}$ & $\begin{array}{l}-0.019^{*} \\
(0.010)\end{array}$ & $\begin{array}{l}-0.014 \\
(0.013)\end{array}$ \\
\hline Parent advertising/total sales & $\begin{array}{c}0.022 \\
(0.096)\end{array}$ & $\begin{array}{c}0.218^{*} \\
(0.120)\end{array}$ & $\begin{array}{c}0.086 \\
(0.106)\end{array}$ & $\begin{array}{c}0.081 \\
(0.135)\end{array}$ \\
\hline Parent R\&D/total sales & $\begin{array}{l}0.626^{* *} \\
(0.271)\end{array}$ & $\begin{array}{c}0.295^{\star} \\
(0.177)\end{array}$ & $\begin{array}{l}0.981^{\star \star \star} \\
(0.270)\end{array}$ & $\begin{array}{l}-0.575^{\star \star *} \\
(0.172)\end{array}$ \\
\hline CFC earnings and profits/ total sales & $\begin{array}{l}-0.043 \\
(0.031)\end{array}$ & $\begin{array}{c}-0.110^{\star * \star} \\
(0.034)\end{array}$ & $\begin{array}{c}0.024 \\
(0.039)\end{array}$ & $\begin{array}{l}-0.093^{* *} \\
(0.036)\end{array}$ \\
\hline Constant & $\begin{array}{l}0.059^{\star * \star} \\
(0.016)\end{array}$ & $\begin{array}{l}0.107^{\star \star \star} \\
(0.020)\end{array}$ & $\begin{array}{l}-0.038^{\star *} \\
(0.015)\end{array}$ & $\begin{array}{l}0.100^{* \star *} \\
(0.019)\end{array}$ \\
\hline Adjusted $\mathrm{R}^{2}$ & 0.10 & 0.08 & 0.20 & 0.14 \\
\hline Mean of dependent variable & .232 & .215 & .238 & .224 \\
\hline Number of observations & 1865 & 1327 & 1865 & 1327 \\
\hline
\end{tabular}

Notes: ${ }^{*},{ }^{* \star},{ }^{\star \star *}$ denote significance at the 10 percent, 5 percent, and 1 percent level respectively. Standard errors in parentheses.

Source: Treasury tax files. 
Table 5A

Comparison of Income Shifting in 1996 and 2000

Dependent Variable is Pre-Tax Earnings and Profits/CFC Sales (All Manufacturing CFCs with Positive Income)

\begin{tabular}{lcc}
\hline \hline & $\mathbf{1 9 9 6}$ & $\mathbf{2 0 0 0}$ \\
\hline CFC age $<5$ years & -.0021 & .0296 \\
CFC age 5-15 years & $.0046)$ & $(.0042)$ \\
& .0085 & .0056 \\
Parent R\&D/Sales & $.0033)$ & $(.0040)$ \\
& .8833 & .7230 \\
Parent Advertising/Sales & $.0865)$ & $(.0542)$ \\
& .5207 & .8278 \\
Statutory Tax Rate & $(.0359)$ & $(.0457)$ \\
& -.1495 & -.2363 \\
Constant Term & $(.0109)$ & $(.0157)$ \\
& .1225 & .1401 \\
\hline Number of Observations & $(.0046)$ & $(.0059)$ \\
\hline \hline Mean of Dependent Variable & 6093 & 6887 \\
\hline \hline
\end{tabular}

Notes: Observations are weighted by CFC sales. Standard errors are in parenthesis. 
Table 5B

Comparison of Income Shifting in 1996 and 2000

Dependent Variable is Pre-Tax Earnings and Profits/CFC Sales

(Manufacturing CFCs with Positive Income Among 7500 Largest CFCs)

\begin{tabular}{lcccc}
\hline \hline & \multicolumn{2}{c}{1996} & \multicolumn{2}{c}{2000} \\
\cline { 2 - 5 } & Unweighted & Weighted & Unweighted & Weighted \\
\hline Age <5 years & .0050 & -.0002 & .0014 & .0326 \\
Age 5-15 years & $.0107)$ & $(.0088)$ & $(.0112)$ & $(.0101)$ \\
& .0094 & .0105 & .0142 & .0057 \\
Parent R\&D/Sales & $. .0073)$ & $(.0061)$ & $(.0099)$ & $(.0098)$ \\
& .5807 & .9809 & .5721 & .7921 \\
Parent Advertising/Sales & $(.2023)$ & $(.1596)$ & $(.1409)$ & $(.1274)$ \\
& .2895 & .6314 & .2405 & 1.021 \\
Statutory Tax Rate & $(.0782)$ & $(.0677)$ & $(.1088)$ & $(.1105)$ \\
Constant Term & -.1710 & -.1564 & -.2518 & -.2600 \\
& $(.0276)$ & $(.0200)$ & $(.0407)$ & $(.0367)$ \\
& .1713 & .1189 & .1955 & .1402 \\
Mean of Dependent Variable & .1305 & .0972 & .1390 & .1131 \\
\hline \hline Number of Observations & 1865 & 1865 & 1327 & 1327 \\
\hline \hline
\end{tabular}

Notes: Weighting is by CFC sales. Standard errors are in parenthesis. 
Table 6

Tabulations from the 1996 and 2000 Form 5471 Files

(in billions of dollars)

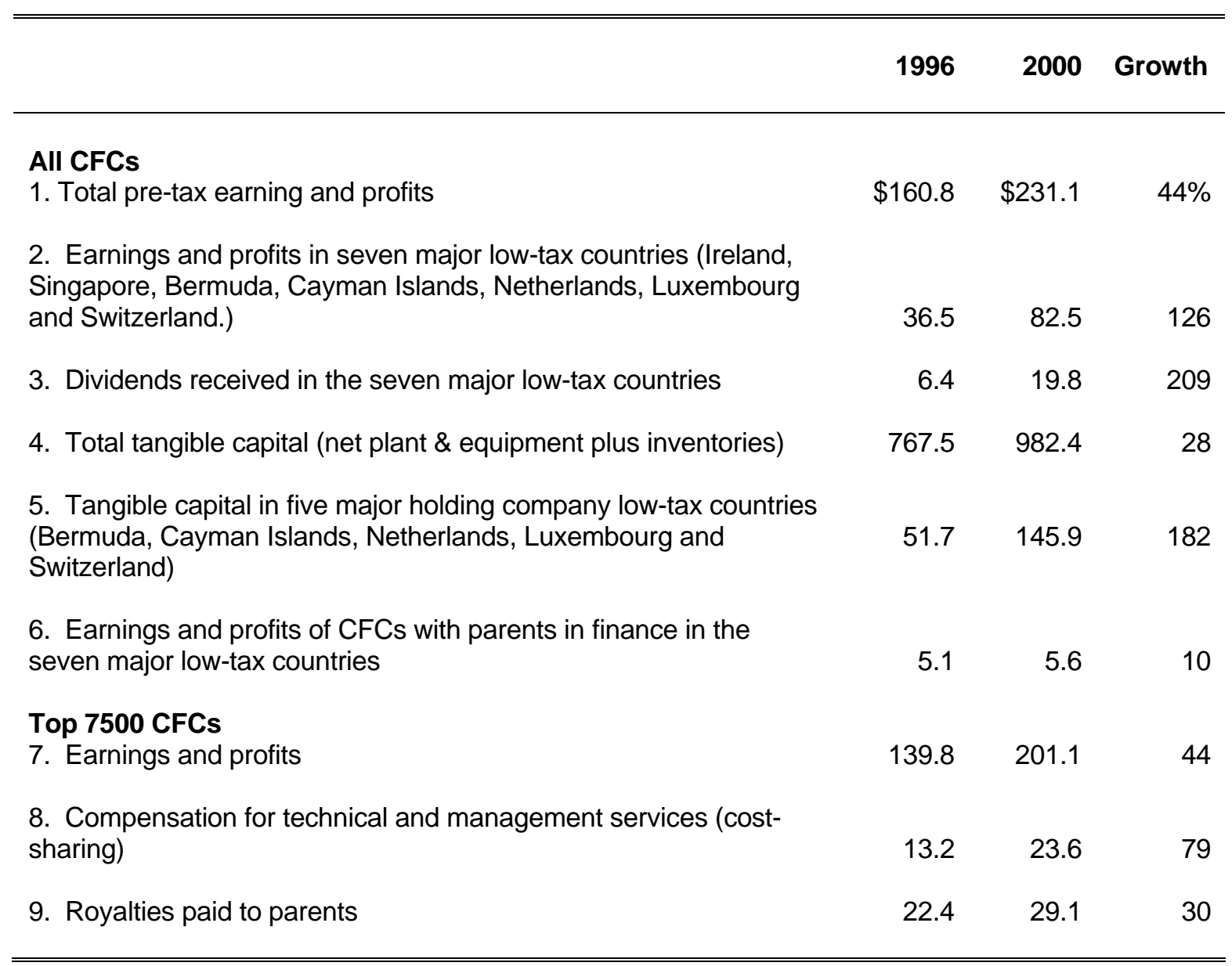

Source: Treasury tax files. 
Table 7

Growth of Equity Income in Affiliates

(in millions of dollars)

\begin{tabular}{|c|c|c|c|c|c|c|}
\hline & $\begin{array}{c}\text { Income from } \\
\text { equity } \\
\text { investments }\end{array}$ & $\begin{array}{l}\text { Pre-tax } \\
\text { income }\end{array}$ & $\begin{array}{c}\text { Income from } \\
\text { equity } \\
\text { investments }\end{array}$ & $\begin{array}{l}\text { Pre-tax } \\
\text { income }\end{array}$ & $\begin{array}{c}\text { Growth in } \\
\text { income from } \\
\text { equity } \\
\text { investments }\end{array}$ & $\begin{array}{l}\text { Growth in } \\
\text { pre-tax } \\
\text { income }\end{array}$ \\
\hline & 1997 & 1997 & 2002 & 2002 & $1997-2002$ & $1997-2002$ \\
\hline All countries & $\$ 41,781$ & $\$ 188,092$ & $\$ 120,782$ & $\$ 255,225$ & $189 \%$ & $36 \%$ \\
\hline \multicolumn{7}{|c|}{ Selected low-tax countries } \\
\hline Ireland & 1,414 & 9,359 & 8,502 & 26,835 & 501 & 187 \\
\hline Luxembourg & 1,935 & 2,352 & 18,995 & 18,405 & 882 & 683 \\
\hline Netherlands & 9,249 & 17,612 & 15,238 & 20,802 & 65 & 18 \\
\hline Switzerland & 6,326 & 9,709 & 11,515 & 14,105 & 82 & 45 \\
\hline Bermuda & 1,649 & 5,933 & 22,142 & 25,212 & 1,243 & 325 \\
\hline Cayman Islands & 1,046 & 2,678 & 2,268 & 2,809 & 117 & 5 \\
\hline Singapore & 578 & 5,765 & 2,465 & 7,533 & 326 & 31 \\
\hline Total & 22,197 & 53,408 & 81,125 & 115,701 & 265 & 117 \\
\hline
\end{tabular}

Source: Department of Commerce, Bureau of Economic Analysis. 
Appendix

Country Database*

Argentina

Australia

Austria

Belgium

Brazil

Canada

Chile

China

Colombia

Costa Rica

Denmark

Dominican Republic

Ecuador

Egypt

El Salvador

Finland

France

Germany

Greece

Guatemala

Honduras

Hong Kong

India

Indonesia

Ireland

Israel

Italy

Jamaica

Japan

Kenya

Luxembourg

Malaysia

Mexico

Morocco

Netherlands
New Zealand

Nigeria

Norway

Pakistan

Panama

Peru

Philippines

Portugal

Singapore

South Africa

South Korea

Spain

Sri Lanka

Sweden

Switzerland

Taiwan

Thailand

Turkey

United Kingdom

Uruguay

Venezuela

Zambia

Zimbabwe

*The subsidiary level regressions included Bermuda and the Cayman Islands. 